\title{
DETERMINANTS OF EXCHANGE RATE VOLATILITY AND ITS IMPLICATION ON THE NIGERIAN ECONOMY (1995-2020)
}

\author{
Andabai Priye Werigbelegha (Ph.D) ${ }^{1}$ and Ogaga Timiepere Cornelius ${ }^{2}$ \\ ${ }^{1}$ Department of Banking and Finance, Niger Delta University, Bayelsa State. \\ ${ }^{2}$ Department of Banking and Finance, Federal University, Otuoke, Bayelsa State.
}

Cite this article:

Andabai P.W., Ogaga T.C. (2021), Determinants of Exchange Rate Volatility and Its Implication on the Nigerian Economy (1995-2020).

African Journal of Economics and Sustainable Development 4(2), 29-38. DOI:

10.52589/AJESD-6CR94Z5I.

\section{Manuscript History}

Received: 21 Feb 2021

Accepted: 23 March 2021

Published: 20 July 2021

Copyright $\odot 2020$ The Author(s). This is an Open Access article distributed under the terms of Creative Commons AttributionNonCommercial-NoDerivatives 4.0 International (CC BY-NC-ND 4.0), which permits anyone to share, use, reproduce and redistribute in any medium, provided the original author and source are credited.
ABSTRACT: The study investigates the determinants of exchange rate volatility and its implication on the growth of the Nigerian economy; for the period (1995-2020). Secondary data were collected from the Central Bank of Nigeria Statistical Bulletin, 2020. The study employs Gross Domestic Product as proxy for the Nigerian economy and used as the dependent variable; whereas, exchange rate, import trade and export trade were used as explanatory variables to measure exchange rate fluctuation. Time series econometric techniques are used to test the hypotheses. Exchange rate has an insignificant impact on Gross Domestic Product in Nigeria. Import trade has a significant impact on Gross Domestic Product in Nigeria. Export trade has a significant impact on Gross Domestic Product in Nigeria. The error-correction result confirms that about $71 \%$ short-run adjustment speed from long-run disequilibrium. The coefficient of determination indicates that about $68 \%$ of the variations in the growth of the Nigerian economy can be explain by changes in exchange rate volatility variables. The study concludes that exchange rate fluctuation is positive; but, had a significant impact on the performance of the Nigerian economy. The study recommends that Government should encourage the export promotion strategies in order to maintain a surplus balance of trade and also conducive environment, adequate security, effective fiscal. The policy towards interest rate should be made such that savings would be stimulated thereby placing more funds in the hands of banks to intermediate to investors seeking funds. Government and policy makers should provide infrastructural facilities so that foreign investors will be attracted to invest in Nigeria. Government and policy makers should increase their surveillance on the commercial banks; in order to address the issue of arbitrarily increase of the exchange rate.

KEYWORDS: Determinants, Exchange Rate, Volatility, Nigerian Economy. 


\section{INTRODUCTION}

No country is an island of its own in this globalized world; indeed, economies of all the countries of the world are linked directly or indirectly and this is made possible through trade in foreign exchange (Adeolu \& Chiwendu, 2018). Hence, the movement of goods and services across national frontiers in involves the movement of foreign exchange in the various direction. The study conducted by Ademola, Tajudeen and Adewumi (2018) described exchange rate as the price of one country's currency expressed in terms of some other currency. It determines the relative prices of domestic and foreign goods, as well as the strength of external sector participation in the international trade. Thus, increase in prices of goods and services and foreign exchange rates are some of the important aspects which are deemed responsible for potholed fluctuations in the growth of the economy.

The work of Aderemi, Salami and Tonju (2018) identified some factors which cause variations in the exchange rate as: government policy, interaction of demand and supply, activities of the Nigerian Stock Exchange (NSE), international trade oil glut and recession. A country's foreign exchange policy is derived from the perceived overall economic objective to be achieved and the expected direction of growth. Since independence in 1960, Nigeria has employed diverse exchange rate policies in an attempt to attain a realistic exchange rate that would ensure efficient allocation of foreign exchange and allow for non-inflationary growth of the economy. Specifically, in a bid to achieve macroeconomic stability, Nigeria's monetary authorities have adopted various exchange rate arrangements over the years. Exchange rate regime and interest rate remain important issues of discourse in the international finance as well as in developing nations, with more economies embracing trade liberalization as a necessity for economic growth (Bala \& Hassan, 2018). In Nigeria, exchange rate has changed within the time frame from regulated to deregulated regimes.

The work carried out by Olukayo and Burderen (2018) revealed that exchange rate of the Nigerian currency was relatively stable between 1973 and 1979 during the oil boom era and when agricultural products accounted for more than $70 \%$ of the nation's Gross Domestic Product (GDP). In 1986 when Federal government adopted Structural Adjustment Policy (SAP) the country moved from a peg regime to a flexible exchange rate regime where exchange rate is left completely to be determined by market forces. Dauda and Ahudu (2018) noted that appreciation of exchange rate results in increased imports and reduced in export while depreciation would expand export and discourage import. However, depreciation of exchange rate tends to cause a shift from foreign goods to domestic goods. Thus, it leads to diversion of income from importing countries to countries exporting through a shift in terms of trade, and this tends to have impact on the countries' balance of payment. Consequently, a number of exchange rate reforms have been carried out by successive governments; but, the extent to which these policies have been effective in promoting export trade has remained unascertained.

\section{Theoretical Framework}

This study is predicated on the balance of payments theory. The theory posits that the exchange rates are determined by the balance of payment. It holds that the price of foreign money in terms of domestic money is determined by the free forces of demand and supply in the foreign exchange market (Jin, 2018). The theory stated that a deficit in the balance of payments leads to fall or depreciation in the rate of exchange, while a surplus in the balance of payment strengthens the foreign exchange reserves, causing an appreciation in the price of home 
currency (Okorontha \& Odoemena, 2018). A deficit balance of payments of a country implies that demand for foreign exchange is exceeding its supply, thus, the price of foreign money in terms of domestic currency must rise i.e. the exchange rate of domestic currency must fall.

On the other hand, a surplus in the balance of payments of the country implies a greater demand for home currency in a foreign country than the available supply. As a result, the price of home currency ion terms of foreign money rises i.e. the rate of exchange improves. According to the balance of payment theory, the demand for foreign exchange arises from the "debit" items in the balance of payments whereas, the supply of foreign exchange arises from the "credit" items. Since the theory assumes that the demand for and supply of foreign currency are determined by the position of the balance of payments, it implies that supply and demand are determined mainly by factors that are independent of variations in the rate of exchange or the monetary policy (Eme \& Johnson, 2020). Given the demand-supply schedules, their intersection determines the equilibrium exchange rate of a currency.

\section{Empirical Review}

Gylych, Abdullahi, Ahmad and Abdurahman (2017) analyzed impact of exchange rate on gross domestic product and other macroeconomic aggregates in Nigeria. The study covers the period from 1990 to 2016 to establish direct and indirect relationships between exchange rate and other macroeconomic indicators. Results indicate that there are unidirectional relationships between real GDP and inflation, and interest rate and inflation; while we have bi-directional relationship between exchange rate and inflation, and between inflation and interest rate.

King-George (2015) examined the effect of exchange rate fluctuation in the manufacturing sector was set to find out the effect of exchange rate on the Nigerian manufacturing sector. Hypothesis was stated to guide the study. To evaluate this hypothesis, annual times series data on manufacturing gross domestic product a proxy for economic growth, exchange rate, private foreign investment had manufacturing output employment rate were collected from the year 1986 to 2016.

Ogbekere and Susan (2019) investigated capital flight and real exchange rate in Nigeria from 1996 to 2016. The study used five independent variables (capital flight, foreign direct investment, current account balance, foreign borrowing and external reserves) and one dependent variable (real exchange rate). The study revealed that: There is a positive significant relationship between foreign borrowing and real exchange rate in Nigeria, there is a negative and insignificant relationship between capital flight and real exchange rate in Nigeria, there is positive and insignificant relationship between foreign direct investment and real exchange rate in Nigeria, there is negative insignificant relationship between current account balance and real exchange rate in Nigeria.

Olukayo and Burderen (2018) studied the impact of exchange rate instability on the export of both oil and non-oil areas (1998-2015). The paper utilized the econometrics strategy for GARCH in measuring instability of conversion scale and apparently disconnected relapse technique (SUR) in assessing the coefficient of the two-framework condition. Curve and GARCH comes about recommended that the swapping scale is unpredictable, while SUR display demonstrates that conversion standard has negative impact on the two divisions however factually not noteworthy. 


\section{Methodology}

The study applied ex-post-facto research design to source requisite information. An ex-postfacto research design is a systematic empirical inquiry that requires the use of variables which the researcher does not have the capacity to change its state or direction in the course of the study (Onwumere, 2009). The study employed Gross Domestic Product as proxy for the Nigerian economy and used as the dependent variable; whereas, exchange rate, import trade and export trade were used as explanatory variables to measure exchange rate.

\section{Model Specification}

Multivariate linear regression models are used to test the null hypotheses proposed for the study. Exchange rate volatility does not have any significant implication on the Nigerian economy. Based on that a model is adapted from the work of (Chiwendu \& Ogbonna, 2019). Hence, the model is stated as: GDP $=f(\mathrm{EXR}, \mathrm{IMT}$, INFL $)$

Where: GDP $=$ Gross Domestic Product as proxy for the Nigerian economy.

$\mathrm{EXR}=$ Exchange Rate

IMPT $=$ Import Trade

INFL = Inflation Rate

The above model is modified in this study by introducing export trade as proxy for inflation rate and was employed as independent variable. Hence, the modified model is stated as:

$\mathrm{GDP}=f(\mathrm{EXR}, \mathrm{IMPT}, \mathrm{EXPT})$.

The econometric model can be written as:

$L N(\mathrm{GDP})=\delta_{0}+\delta_{1} L N \mathrm{EXR}+\delta_{2} L N \mathrm{IMPT}+L N \delta_{3} \mathrm{EXPT}+\mu$.

Where: GDP $=$ Gross Domestic Product as proxy for the Nigerian economy.

EXR $=$ Exchange Rate, $\mathrm{IMPT}=$ Import Trade, EXPT $=$ Export Trade

\section{DATA PRESENTATION AND DISCUSSION}

The study focused on the determinants of exchange rate volatility and its implication on the Nigerian economy; for the period (1995-2020) as revealed on appendix 1.

Table 1: Descriptive statistics

$\begin{array}{lcccc} & \text { GDP } & \text { EXPT } & \text { IMPT } & \text { EXR } \\ \text { Mean } & 88365.27 & 66346.67 & 58353.70 & 38.86763 \\ \text { Median } & 57566.83 & 53664.58 & 48561.79 & 23.96750 \\ \text { Maximum } & 47386.87 & 66237.81 & 50231.79 & 32.10000 \\ \text { Minimum } & 37564.46 & 47695.83 & 45363.67 & 22.10000 \\ \text { Std. Dev. } & 61468.02 & 19102.05 & 47689.86 & 9.617132 \\ \text { Skewness } & 0.285252 & 3.104248 & 1.0670 .69 & 0.185586\end{array}$


African Journal of Economics and Sustainable Development

ISSN: 2689-5080

Volume 4, Issue 2, 2021 (pp. 29-38)

www.abjournals.org

$\begin{array}{lcccc}\text { Kurtosis } & 3.070332 & 14.12550 & 5.2562 .20 & 2.604247 \\ \text { Jarque-Bera } & 0.41578 & 272.1536 & 12.79560 & 0.374544 \\ \text { Probability } & 0.06295 & 0.078354 & 0.074652 & 0.065799 \\ \text { Sum } & 134.3120 & 3243.310 & 436.4000 & 1486.929 \\ \text { Sum Sq. Dev. } & 32153.57 & 438604.4 & 616.1700 & 2152.166 \\ \text { Observations } & 26 & 26 & 26 & 26\end{array}$

Source: Author's computation with the use of E-view 9.1

The descriptive statistics result on table 1 shows that Gross Domestic Product for the period under study had a mean value of $\$ 88,365.27$, export trade had $\$ 68,843.70$ and import trade had $\$ 58,353.70$; while, exchange rate had $38.24 \%$. The Jarque-Bera statistic shows that two of the variables, namely Gross Domestic Product and export trade were normally distributed while export trade and exchange rate were highly skewed. Furthermore, Gross Domestic Product has a mean of $\$ 75,648.27$ this implies that for the period under review the Gross Domestic Product was very high; because, the determinants of exchange rate volatility had a significant implication on the Nigerian economy.

\section{Unit Root Test}

The test for stationary of the variables was done using the Augmented Dicker Fuller (ADF) Unit Root Test. The results on table 2 show that all the variables are integrated at levels i.e. $1(1)$ at the $5 \%$ or $1 \%$ level of significance.

Table 2: Unit Root Tests Analysis

\begin{tabular}{|l|c|l|l|l|}
\hline \multicolumn{1}{|c|}{ Variables } & $\begin{array}{c}\text { ADF test } \\
\text { Statistics }\end{array}$ & $\begin{array}{l}\text { Mackinnon } \\
\text { critical value }\end{array}$ & $\begin{array}{c}\text { No of the time } \\
\text { difference }\end{array}$ & \multicolumn{1}{c|}{ Remark } \\
\hline GDP & 3.6389745 & -3.756408 & $1(\mathrm{I})$ & $1(\mathrm{I})$ \\
EXR & -6.2436876 & -3.846506 & $1(\mathrm{I})$ & Stationary \\
EXPT & 4.8796980 & -2.746578 & Stationary \\
IMPT & 3.3658990 & -2.968767 & $1(\mathrm{I})$ & Stationary \\
\hline
\end{tabular}

Notes: (1)1\% level of significance, $5 \%$ level of significance, $10 \%$ level of significance. (2) The tests accepted at 5\% level of significance. (3) Decision rule -The critical value should be larger than the test statistical value for unit root to exist. Source: Researcher's Estimation using- E-views 9.1

\section{Test for Co-Integration}

Having found that all the variables are stationary at first difference; thus, the next step is to perform Johansen co-integration procedure to ascertain whether Gross Domestic Product, exchange rate, export trade and import trade are co-integrated in the same order. The results of the test are presented on table 3 . 
Table 3: Multivariate Johansen's Co-Integration Test Result.

\begin{tabular}{|l|l|l|l|l|l|l|}
\hline $\begin{array}{l}\text { Null } \\
\text { hypotheses }\end{array}$ & $\begin{array}{l}\text { Alternative } \\
\text { hypotheses }\end{array}$ & Eigen value & $\begin{array}{l}\text { Likelihood } \\
\text { ratio }\end{array}$ & $\begin{array}{l}\text { Critical vale } \\
5 \%\end{array}$ & $\begin{array}{l}\text { Critical value } \\
1 \%\end{array}$ & $\begin{array}{l}\text { Hypothesized } \\
\text { No. of CE(s) }\end{array}$ \\
\hline $\mathrm{r}=0$ & $\mathrm{r}=1$ & 0.7435267 & 52.43635 & 62.84 & 44.02 & None ** \\
\hline $\mathrm{rd} \leq 1$ & $\mathrm{r}=2$ & 0.7254736 & 51.53785 & 51.03 & 32.34 & At most 1 \\
$\mathrm{rd} \leq 2$ & $\mathrm{r}=3$ & 0.6476857 & 46.03093 & 44.76 & 20.63 & At most 2 \\
$\mathrm{rd} \leq 3$ & $\mathrm{r}=4$ & 0.6274535 & 43.84659 & 38.56 & 20.85 & At most 3 \\
\hline
\end{tabular}

Source: E-views Econometrics 9.1. Note* $(* *)$ denotes rejection of hypothesis at 5\% (1\%) significance level.

\section{Vector Error Correction Model}

The Error Correction coefficient contains information about whether the past values affect the current values of the variable under study and the significant coefficient implies that past equilibrium errors play a role in determining the current outcomes (Ibenta, 2012).

\section{Table 4: Vector Error Correction Estimates Results}

Dependent Variable: GDP

Method: Least Squares, Time: 04:42

Sample: 1995-2020

Included observations: 26

\begin{tabular}{lllll} 
Date: $17 / 02 / 2021$ & Coefficient & Std. Error & t-Statistic & Prob. \\
\hline \hline (ECM)(-1) & -0.716235 & 0.037542 & 12.03084 & 0.000010 \\
D(GDP-1) & 132.2678 & 0.036552 & 0.645325 & 0.000040 \\
D(GDP-2) & 152.7678 & 0.046573 & 0.352733 & 0.000008 \\
C & 3.603088 & 0.005234 & 1.635486 & 0.000031 \\
$L N($ EXR) & 5.367356 & 0.002709 & -0.343565 & 0.000020 \\
$L N(I M P T)$ & 12.03783 & 0.004653 & 2.325468 & 0.000032 \\
$L N($ EXPT) & 183.0247 & 0.001324 & 1.386579 & 0.000014 \\
\hline \hline R-Squared & 0.682784 & Mean dependent var. & 134.6543 \\
Adjusted R-squared & 0.646152 & S.D. dependent var. & 132.4356 \\
S.E. of regression & 142.3756 & Akaike info criterion & 214.0312 \\
Sum squared resid & 163.3220 & Schwarz criterion & 130.4362 \\
Log likelihood & -123.1673 & F-statistic & 6.675869 \\
Durbin-Watson stat & 1.982321 & Prob(F-statistic) & 0.000000 \\
\hline \hline
\end{tabular}

Source: Author's computation with the use of E-view 9.1

The results on table 4 show that error-correction coefficient (-0.711249) is statistically significant and has a negative sign, which confirms a necessary condition for the variables to be co-integrated. Hence, there is a long-run equilibrium impact of exchange rate on the performance of Nigerian economy; and, the result confirms that about $71 \%$ short-run adjustment speed from long-run disequilibrium. However, coefficient of determination $\left(\mathrm{R}^{2}=\right.$ 0.682784 ) indicates that about $68 \%$ of the variations in the Nigerian economy can be explained 
by changes in exchange rate volatility variables (EXR, IMPT and EXPT) in Nigeria. This implies that a significant portion of economy is explained by exchange rate variables. The $\mathrm{p}-$ value of (0.000000) indicates that there is a significant impact of exchange rate on Gross Domestic Product in Nigeria; this is because, the F-probability is statistiscally zero. This means that exchange rate volatility has a significant impact on the Nigerian economy; because, the influence of the explanatory variables on the dependent variable is statistically significant and this is also confirmed by the F-probability which is statistically zero.

\section{Test of Hypotheses}

Ho1: There is no significant implication of exchange rate on Gross Domestic Product in Nigeria. Decision Criteria: Level of significance $(\alpha)$ : $0.05(5 \%)$, Decision Rule: Reject $\mathrm{H}_{0}$ : If p- value $<0.05$ and accept $\mathrm{H}_{0}$ if $\mathrm{p}$ - value $>0.05$. The results on table 4 reveal that exchange rate has a t-statistic of -0.343565 with a probability of 0.000020 which is lower than the level of significance of 0.05 , which means, its implication is statistically significant. The null hypothesis is, therefore, rejected. Thus, there is a significant impact of exchange rate on Gross Domestic Product in Nigeria $\mathbf{H o}_{2}$ : There is no significant impact of import trade on Gross Domestic Product in Nigeria. Decision Rule: Reject $\mathrm{H}_{0}$ : If $\mathrm{p}$ - value $<0.05$ and accept $\mathrm{H}_{0}$ if $\mathrm{p}$ value $>0.05$. The results on table 4 show that import trade has a t-statistic of 2.325468 with a probability of 0.000032 which is lower than the level of significance of 0.05 , which means, hence, its impact is statistically significant. The null hypothesis is, therefore, rejected. Thus, import rate has a significant impact on Gross Domestic Product in Nigeria. Ho3: Export trade has no significant impact on Gross Domestic Product in Nigeria. Decision Rule, Reject Ho: If p- value $<0.05$ and accept $\mathrm{H}_{0}$ if $\mathrm{p}$ - value $>0.05$. The results on table 4 show that export trade has a t-statistic of 1.386579 with a probability of 0.000014 which is lower than the level of significance of 0.05 , which means, hence, its impact is statistically significant. The null hypothesis is, therefore, rejected. Thus, export trade has a significant impact on Gross Domestic Product in Nigeria.

\section{CONCLUSION AND RECOMMENDATIONS}

The study concludes that exchange rate volatility is positive; and, has a significant implication on the Nigerian economy; this is evident from the Ordinary Least Square (OLS) econometrics test as indicated on table 4. This corroborates the work of Olukayo and Burderen (2019) which revealed a positive and significant effect of exchange rate on economic growth in Nigeria. Thus, the study recommends that the regulatory should encourage the export promotion strategies in order to ensure a surplus balance of trade and also conducive environment. Effective fiscal and monetary policies, as well as infrastructural facilities should be provided so as to attracted foreign investors to Nigeria. Monetary authorities should increase their surveillance on the commercial banks; in order to address the issue of arbitrarily increase of the exchange rate. Proper integration of the financial sector should be ensured by the government so that financial units can be strategically positioned and capable to intermediate funds. Government and policy makers should implement policies that will increase the flow of investable funds and improves the capacity of banks to extend credit to the economy. Government should provide healthy environment for the financial industry; so as to render efficient and effective financial services in the economy. 


\section{Contribution to Knowledge}

This study was able to modify the model, expansion of the existing literature, geographical spreads and updated the data of the study that will enable researchers and scholars to use it for further studies. The study concludes that exchange rate volatility has a significant implication on the Nigerian economy.

\section{REFERENCES}

Adelowokan, O.A, Adesoye, A. B., \& Balogun, O. D (2018). Exchange rate volatility on investment and growth in Nigeria: An empirical analysis. Global Journal of Management and Business Research, 5(10), 23-32.

Ademola, S.S. Tajudeen, O.A. \& Adewumi, A. Z. (2018). Effect of exchange rate on economic growth of Nigeria: An empirical investigation. South Asian Journal of Social Studies and Economics, 1(2), 1-11.

Adeolu, D \& Chiwendu, B. T (2018). The determinants of exchange rate and the Nigeria economy. International Business Management and Research, 23(8), 241-246

Aderemi, S.K, Salami, S \& Tonju, S (2018). The effect of exchange rate fluctuation on the economic Growth in Nigeria. International Journal of Finance and Business Research, 23(9), 123-134

Aliyu, S.R.U. (2018). Impact of oil price shock and exchange rate volatility on economic growth in Nigeria: An empirical investigation. Research Journal of International Studies, 23(8), 12-23.

Andabai, P. W. \& MaryAnn, N. I. (2018). International trade and performance of the Nigerian economy. Research Journal of Finance and Accounting, 9(4), 166-171.

Ayinde, T.O. (2018). The impact of exchange rate instability on manufacturing performance in Nigeria. Fountain Journal of Management and Social Sciences. 3(2) 83-92.

Benson, U. O. \& Victor, E. O. (2012). Real exchange rate and macro-economic performance. Journal on International money and Finance, 4(2), 127-134.

Eme, O. A. \& Johnson, A. A. (2017) Effects of exchange rate movement on economic growth in Nigeria. CBN Journal of Applied Statistics, 2(2),1-28.

Ibenta, Steve, N. O.2012). Research Monograph: Guidelines for Seminars Papers, Thesis \&Projects Reports. 22-28 Regina Caeli Rd, Awka Anambra State , Nigeria.

Nzotta, S. M. (2014). Money, Banking and Finance: Theory and Practice. Owerri: HudsonJude, Nigeria Publisher.

Ogbekere \& Susan (2019). Capital flight and real exchange rate in Nigeria. International Journal of Advanced Research in Statistics, Management and Finance, 2(1), 15-25.

Ogun, O. (2017). Real exchange rate behavior and non-oil export in Nigeria. African Journal of Economic Policy, 11(1), 12-23.

Okorontha, C. F. \& Odoemena, I. U. (2018). Effects of exchange rate fluctuations on economic growth of Nigeria. International Journal of innovative Finance and Economics Research, 4(2), 1-7.

Olukayo, E.B. \& Burderen, G. F (2018). Exchange rate volatility and sectoral export of Nigeria: Case of oil and non-oil Sectors. Journal of Economics and Sustainable Development, 5(4), 10-23

Onwumere, J.U.J. (2009). Business and Economic Research Methods. Enugu: Vougasen Publishers. 
Osuala, A.E., Osuala, K.I.\& Onyeike, S.C. (2013), Impact of inflation on economic growth in Nigeria: A causality test. JORIND, 11(1), 206-216.

Owolabi, A.U \& Adegbite, T.A (2018). The effect of foreign exchange regimes on industrial growth in Nigeria. Global Advanced Research Journal of Economic, Accounting and Finance, 1(6), $1-8$.

Rogoffs K. \& Reinhart (2018). Exchange rate volatility and productivity Growth: The role of financial development. Journal of Monetary Economics, 56(4), 494-513.

Tonye Ogiriki \& Andabai, P. W. (2016). Exchange rate fluctuations and the performance of the Nigerian economy. International Journal of Advanced Research in Statistics, Management and Finance, 5(1); 123-129

Tonye Ogiriki \& Andabai, Priye W. (2016). Exchange rate fluctuations and the performance of the Nigerian economy. International Journal of Advanced Research in Statistics, Management and Finance, 5(1); 123-129

Ubok, D. (2017). Currency depreciation and domestic output growth in Nigeria 19711995.The Nigerian Journal of Economics and Social Studies, 41(1), 31-44. 


\section{APPENDIX}

\section{Exchange Rate and Gross Domestic Product in the Nigerian Economy (1995-2020)}

\begin{tabular}{|l|l|l|l|c|}
\hline YEAR & $\begin{array}{l}\text { GDP at Current } \\
\text { Market Price (N } \\
\text { Billion) }\end{array}$ & $\begin{array}{l}\text { Import Trade } \\
\text { (N'Billion) }\end{array}$ & $\begin{array}{l}\text { Export } \\
\text { Trade(\#' } \\
\text { Billion) }\end{array}$ & $\begin{array}{l}\text { Exchange } \\
\text { Rate (\%) }\end{array}$ \\
\hline 1995 & $1,089.68$ & 165.6 & 218.8 & 65.752 \\
\hline 1996 & $1,399.70$ & 162.8 & 206.1 & 83.695 \\
\hline 1997 & $2,907.36$ & 755.1 & 950.7 & 92.693 \\
\hline 1998 & $4,032.30$ & 562.6 & $1,309.5$ & 102.105 \\
\hline 1999 & $4,189.25$ & 845.7 & $1,241.7$ & 111.943 \\
\hline 2000 & $3,989.45$ & 837.4 & 751.9 & 120.970 \\
\hline 2001 & $4,679.21$ & 862.5 & $1,189.0$ & 129.356 \\
\hline 2002 & $6,713.57$ & 985.0 & $1,945.7$ & 133.500 \\
\hline 2003 & $6,895.20$ & $1,358.2$ & $1,868.0$ & 131.661 \\
\hline 2004 & $7,795.76$ & $1,512.7$ & $1,744.2$ & 128.651 \\
\hline 2005 & $9,913.52$ & $2,080.2$ & $3,087.9$ & 134.054 \\
\hline 2006 & $11,411.07$ & $1,987.0$ & $4,602.8$ & 132.372 \\
\hline 2007 & $14,610.88$ & $2,800.9$ & $7,246.5$ & 132.601 \\
\hline 2008 & $18,564.59$ & $3,108.5$ & $7,324.7$ & 128.270 \\
\hline 2009 & $20,657.32$ & $3,912.0$ & $8,309.8$ & 146.680 \\
\hline 2010 & $24,296.33$ & $5,593.2$ & $10,387.7$ & 150.20 \\
\hline 2011 & $24,794.24$ & $5,480.7$ & $8,606.3$ & 156.00 \\
\hline 2012 & $54,612.26$ & $8,164.0$ & $12,011.5$ & 171.200 \\
\hline 2013 & $62,980.40$ & $10,995.9$ & $15,236.7$ & 180.111 \\
\hline 2014 & $71,713.94$ & $9,766.6$ & $15,139.3$ & 44.527 \\
\hline 2015 & $87,576.474$ & $9,439.4$ & $15,262.0$ & 46.628 \\
\hline 2016 & $94,144.960$ & $10,538.8$ & $12,960.5$ & 32.23 \\
\hline 2017 & $96,165.49$ & $11,076.1$ & $8,845.2$ & 36.12 \\
\hline 2018 & $101,375.76$ & $15,756 . t$ & $10,354.5$ & 36.04 \\
\hline 2019 & $103,536.35$ & $15,986.5$ & $12,347.8$ & 36.63 \\
\hline 2010 & $112,364.75$ & $16,364.9$ & 13.464 .56 & 36.38 \\
\hline
\end{tabular}

Sources: Central Bank of Nigeria Statistical Bulletin, 2020. 